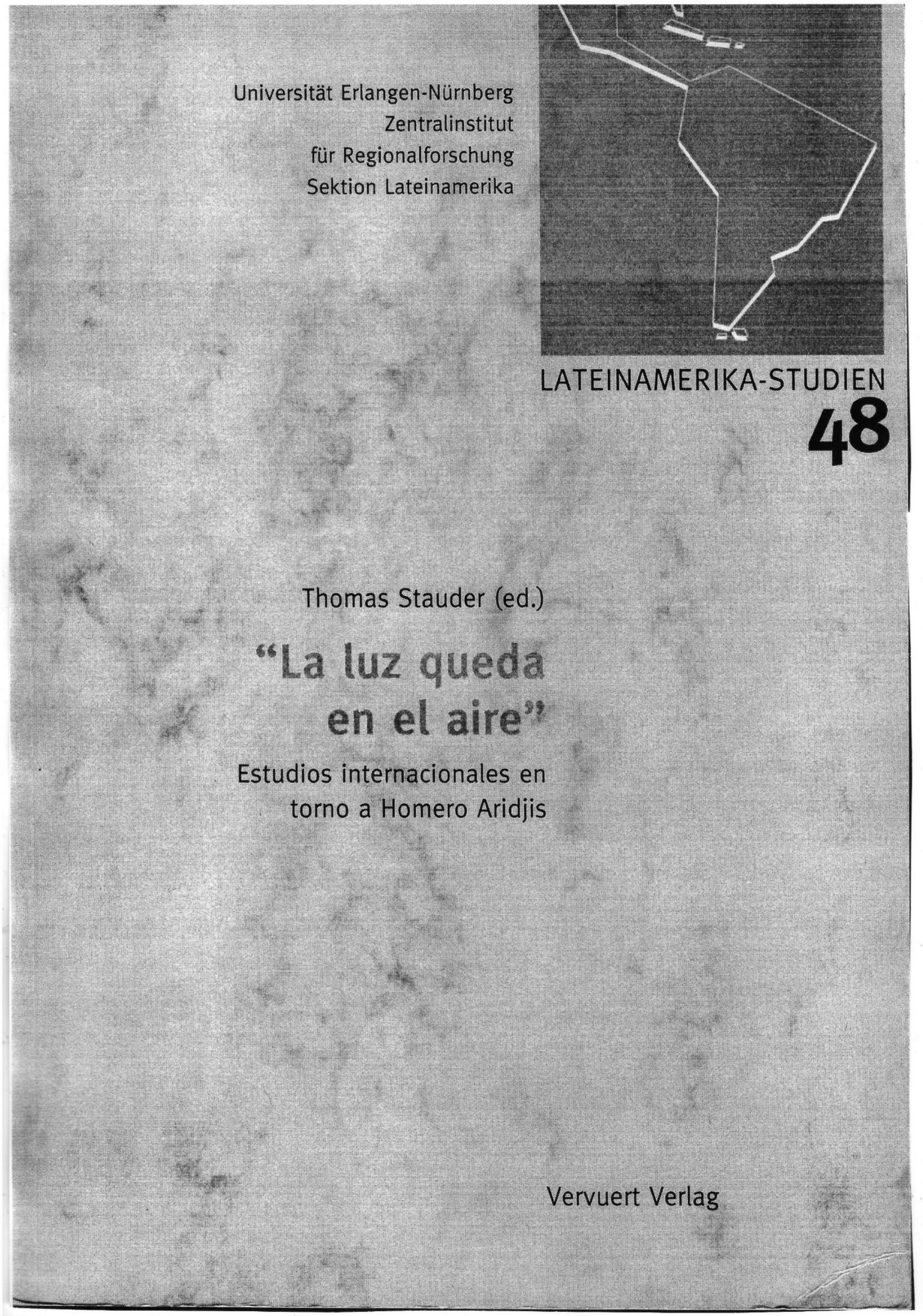




\section{Anschrift der Schriftleitung:}

Universität Erlangen-Nürnberg

Zentralinstitut für Regionalforschung

Sektion Lateinamerika

Bismarckstr. 1

D-91054 Erlangen

Gedruckt mit Unterstützung der

Friedrich-Alexander-Universität Erlangen-Nürnberg

und der Dr.-Alfred-Vinzl-Stiftung

Dedicado a Angela

Bibliographic information published by Die Deutsche Bibliothek

Die Deutsche Bibliothek lists this publication in the Deutsche Nationalbibliografie; detailed bibliographic data are available on the Internet at $h t t p: / / d n b . d d b . d e$.

ISBN 84-8489-210-7 (Iberoamericana)

ISBN 3-86527-219-3 (Vervuert)

(c) by the Editors 2005

Reservados todos los derechos

Cubierta: Michael Ackermann

Este libro está impreso íntegramente en papel ecológico blanqueado sin cloro Impreso en Alemania 


\title{
Un coloquio con Homero Aridjis
}

\author{
THOMAS STAUDER
}

Thomas Stauder: Si usted está de acuerdo, empezaría con una pregunta sobre su cargo como presidente del PEN-Club Internacional. ${ }^{1}$ Quizás podría decirme algo de su trabajo allí desde 1997. He leído en un artículo que usted quiere combatir el eurocentrismo del PEN. ¿Cuáles son sus objetivos concretos?

Homero Aridjis: Bueno, cuando yo entré en el 97, el PEN estaba básicamente concentrado en Europa y en los Estados Unidos, casi no tenía centros en América Latina y muy pocos en África. A mí me interesaba mucho que el PEN fuera realmente una organización internacional, porque la mayor parte de los problemas de libertad de expresión vienen de países no europeos. Por ejemplo, ahora un escritor de Venezuela me dice: "Con la crisis política en Venezuela necesitamos más que nunca el PEN, porque va a haber problemas de arrestos de escritores y periodistas". En Cuba no ha sido posible abrir un centro del PEN; hay uno en el exilio, pero no es lo mismo. Nos interesa que haya centros en Nicaragua, en Guatemala, en Colombia; en todos los países donde se producen agresiones a escritores y periodistas. Esto es lo que estamos buscando. Cuando yo entré en el PEN, mi candidatura era la de un presidente de reforma, con el objetivo de integrar a grupos nuevos. Mi propuesta fue unir la cultura clásica europea — la tradición grecolatina, que llega hasta nuestros días - con las nuevas literaturas. Yo mismo soy mitad europeo, mi padre era griego...

T.S.: Conozco la historia de su familia a través de su novela autobiográfica La montaña de las mariposas.

H.A.: No me iba a alejar de algo que también ha sido una vertiente cultural en mi obra, pero quería tener ojos para las literaturas emergentes. Además, en un mundo de fundamentalismos étnicos, religiosos y políticos, para el PEN es muy necesario mantenerse neutral. Muchas otras organizaciones de escritores caen en la tentación y toman parte, perdiendo de esta manera su independencia. Lo que el PEN tiene de bueno es que en su historia no se ha identificado con grupos políticos; ha logrado mantenerse independiente.

T.S.: En segundo lugar, ¿podría decirme algo sobre el "Grupo de los Cien" y en general sobre sus actividades como defensor del medio ambiente?

H.A.: Yo nací y crecí en un pueblo pequeño de México, en las montañas, a 2.250 metros sobre el nivel del mar; es un pueblo donde tiene su santuario la mariposa monarca, que viene de Canadá en migración anual para pasar el invierno en México. Vuela unos 5.000 kilómetros, es una maravilla; forma colonias como de once millones de ejemplares. Yo crecí con un sentido de la naturaleza muy fuerte, con el amor por los árboles y los animales ya desde niño.

\footnotetext{
${ }^{1}$ En el momento de la entrevista, Homero Aridjis todavía desempeñaba esa función; algunos meses más tarde, a finales del año 2003, el escritor checo Jiři Gruša le sucedió en el cargo.
} 
Ése es el motivo por el cual en mi obra se encuentra siempre la presencia de la naturaleza. Sin embargo, en 1985 el nivel de contaminación en la Ciudad de México fue tan elevado que incluso un día - uno de esos días en que uno cree que se va a caer muerto en la calle - casi se pudo palpar la contaminación y sentirla en la boca. Entonces un amigo filósofo — se llama Ramón Xirau, es catalán- escribió una carta a un periódico diciendo: "En el día de ayer iba en taxi a la universidad para dar mis clases, y debido a la contaminación que había en la ciudad, cambié de rumbo para ir a poner una queja". Leyendo el periódico, le dije a mi esposa Betty: "Qué extraño, ayer yo me encontraba en otra parte de la ciudad, pero también tuve esa impresión de ansiedad y sentía que me iba a morir". Pero no había pensado en mandar una carta, porque en México las cartas no tienen efecto, es como poner un mensaje en una botella, no tiene casi destinatario. Entonces Betty me dijo: "Si todos los que nos quejamos, trabajáramos juntos, podríamos lograr un cambio. ¿Porqué no hablas con Ramón Xirau?” Y él me dijo: “¿Porqué no hablas con Octavio Paz?” Y empezamos a hablar con diferentes escritores y artistas, y todos me respondieron: "Escribe tú el texto y nosotros lo leeremos". De pronto me encontré investigando todo lo referente a la situación ecológica en la Ciudad de México.

El 28 de febrero terminé el texto y recogimos cien firmas de escritores, entre ellos Gabriel García Márquez, Juan Rulfo, Octavio Paz; pintores como Rufino Tamayo o Eleonora Carrington - la última surrealista aquí en México, que estuvo casada con Max Ernst-, arqueólogos como Eduardo Matos Moctezuma, fotógrafos como Manuel Álvarez Bravo. Yo no pensaba formar un grupo ecológico, sino simplemente hacer una declaración común. Pero la respuesta fue tan grande, que al final me vi de líder de un movimiento ecologista sin quererlo. Estos movimientos estaban ya muy avanzados en otras partes - por ejemplo, en los Estados Unidos y en Europa-, pero en México se encontraban en sus inicios, casi no había conciencia ecológica. Entonces emprendimos la defensa de tres de las especies animales que emigran a México. Primero logramos la protección de los santuarios de la mariposa monarca: en el 1986, el gobierno declaró 16.000 hectáreas zona protegida, incluido el cerro de mi pueblo, que es el Cerro Altamirano. Luego la tortuga marina: se estaban matando como 100.000 tortugas marinas al año en México. Emprendimos una campaña muy fuerte y logramos que el gobierno declarara la veda total a la matanza y comercialización de productos de tortuga marina. Y luego en 1988 logramos que el gobierno declarara los lugares donde nace y se reproduce la ballena gris la reserva de la biosfera más grande de la América Latina. Y en 1995 encabezamos la defensa de los santuarios de la ballena gris en Baja California del Sur, donde la Mitsubishi Corporation de Japón y el gobierno de México querían construir la salinera más grande del mundo.

T.S.: En la laguna de San Ignacio. 


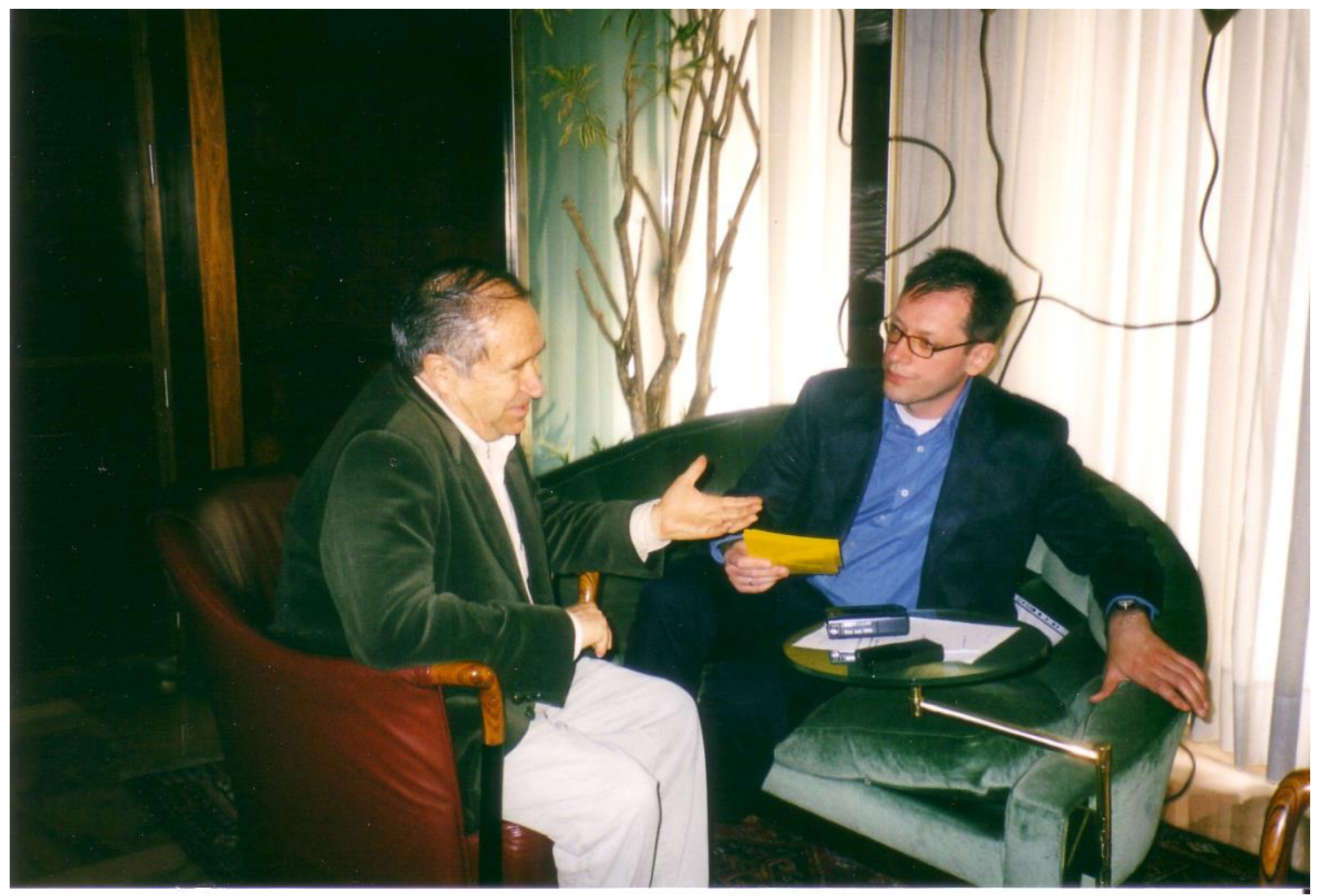

Homero Aridjis y Thomas Stauder durante el coloquio, en Murcia, abril 2003 (foto: Angela Barwig).

H.A.: Sí. Después de cinco años logramos que el gobierno cancelara el proyecto. Entretanto, en 1997, se me amenazó de muerte, y mi mujer y yo vivimos un año bajo protección policial. Mi poema "El ojo de la ballena" se inspiró mucho en esta campaña. Entonces pasé de ser un poeta contemplativo de la naturaleza a ser un poeta activista en defensa de la naturaleza. Los presocráticos entendieron que la fuente de la vida se encontraba en uno (o varios) de los elementos: el agua, el fuego, la tierra, el aire. Para mí, defender los elementos no significa sólo defender las esferas de la vida, para mi son verdaderos conceptos filosóficos. Hay una enorme tradición mística que va desde los poetas antiguos hasta los medievales, como Hildegard von Bingen y San Francisco de Asís, y muchos de los visionarios cristianos occidentales han tenido vínculos con la naturaleza.

T.S.: Tengo otra pregunta más o menos biográfica. He leído un artículo suyo en el cual celebraba el fin de la era del PRI, del Partido Revolucionario Institucional, y la llegada de Vicente Fox a la residencia presidencial de Los Pinos. Por otra parte, en muchas de sus novelas situadas en México - por ejemplo, La leyenda de los soles, de 1993 - aparecen políticos corruptos haciendo causa común con narcotraficantes y otros criminales. ¿Podría decirme cuál es su juicio sobre la situación política actual en México?

H.A.: Mi juicio sobre la clase política en México es de decepción. Lo que he visto es que cambian los partidos, pero no los hombres; es decir que casi los 
hombres son intercambiables a cualquier partido. En general, el político vive para conseguir el poder; y una vez que ha conseguido el poder, vive para conservarlo. Entonces, una vez que ha llegado al poder, olvida o traiciona demasiado a menudo todos sus ideales y propuestas. Un mismo político tiene dos caras: una antes del poder y otra durante su estancia en el poder. O, como se dice en México: una cara antes de sentarse en la silla del presidente, y otra cuando está sentado en esa silla. Para mí, uno de los dramas nacionales de México - pero también del mundo entero- es la mediocridad de los políticos. Yo creo que en algunos momentos históricos ha habido santos y visionarios dirigiendo el país, pero pocas veces; la situación actual es verdaderamente dramática. Hoy en día no se ve políticos que tengan una visión de su país, un concepto de la historia, una conciencia del destino humano o de la vida en general.

Comprendí esto en la Cumbre de la Tierra en 1992, en Río de Janeiro, donde me llevé una gran desilusión porque tenía la esperanza de que esa cumbre sirviera como movimiento de cambio mundial de conciencia, hacia la ecología y la conservación de la tierra. Entonces asistí a algunas reuniones en el cuadro de las Naciones Unidas, donde se estaba redactando la Carta de la Tierra. Pero me desilusioné observando a los delegados de los diferentes países, que pasaban horas y días enteros puliendo las frases hasta volverlas inofensivas y totalmente neutras; todo el trabajo de esos delegados oficiales no fue más que una excusa para que no fuera dicho que no había habido un compromiso para con la tierra, gastando de esta manera mucho tiempo y mucho dinero y perdiendo una oportunidad histórica. En Río de Janeiro los discursos de los jefes de estado fueron todos iguales, desde los países más poderosos hasta los más pequeños: solemnes y retóricos, pero sin llegar a prometer nada en concreto, por ejemplo en lo concerniente a ciertas especies animales.

En cuanto a la situación política en México, antes del cambio yo era un crítico del PRI, del partido en el poder. Cuando entró el nuevo presidente, lo primero que hizo fue anunciar proyectos tan destructivos como los anteriores. Se ha dicho que no somos culpables de la historia, porque la heredamos; pero tampoco somos inocentes, porque la continuamos. Éste es el problema, que muchos políticos no se consideran responsables de la situación en su país, porque la heredaron; pero tampoco son inocentes, porque continúan la misma política anterior. Hay como una especie de "dinámica de la inercia", lo que parece contradictorio.

T.S.: Ahora me gustaría hacer algunas preguntas referentes a su poesía. Empiezo con la importancia que tiene la luz en su obra poética, un hecho observado por muchos críticos. Yo añadiría a esto el papel que tienen ciertos momentos de la existencia en su poesía, breves instantes de belleza y felicidad. He pensado en el concepto de epifanía, tal como fue definido por James Joyce, y que ha sido tan importante para toda la literatura del siglo XX. ¿Podría decirme algo sobre este aspecto de su poesía? 


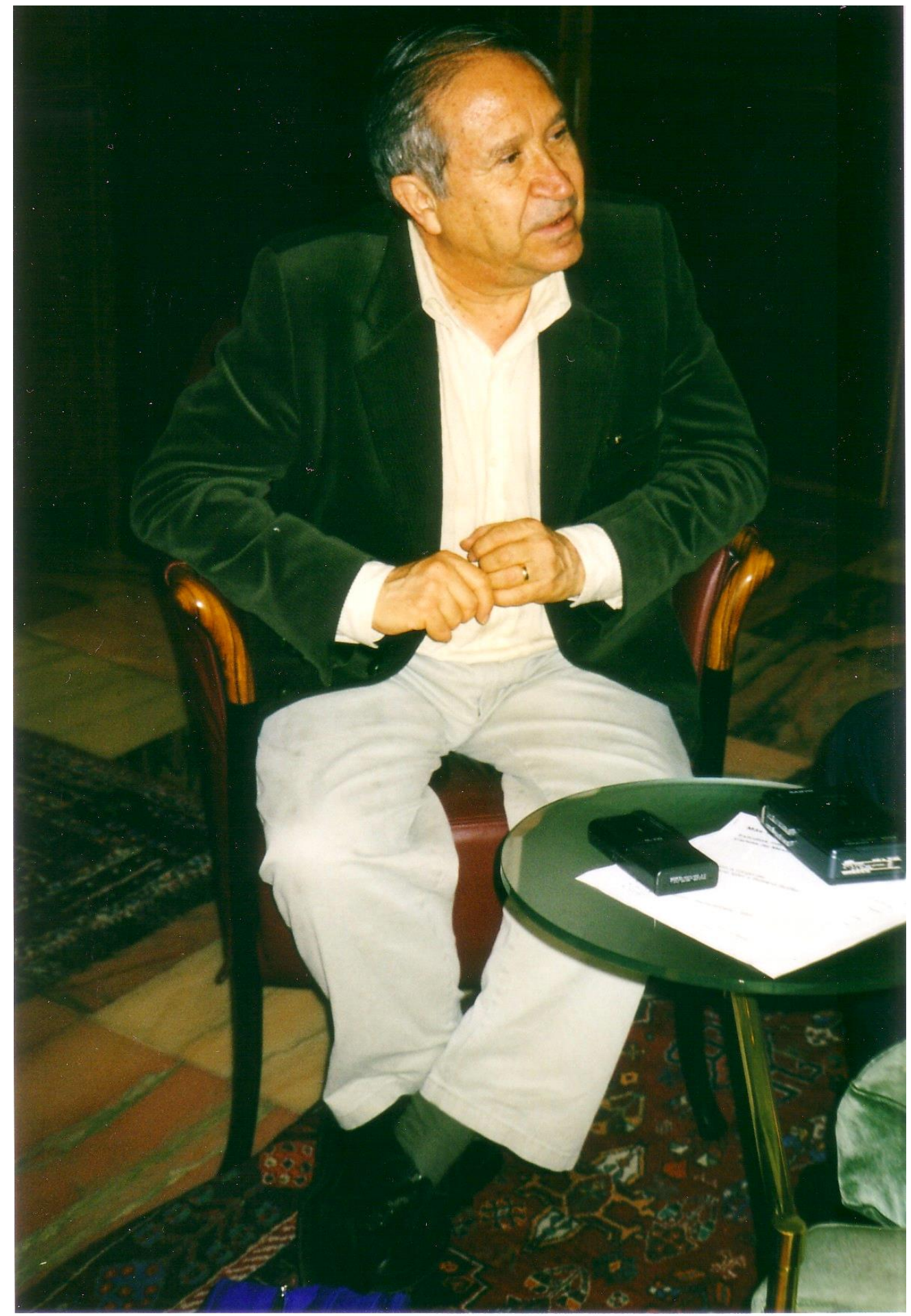

Homero Aridjis durante el coloquio con Thomas Stauder, en Murcia, abril 2003 (foto: Angela Barwig).

H.A.: Yo creo que la felicidad humana consiste precisamente en los breves momentos de la vida cotidiana: cuando uno percibe la luz, un amanecer 
muy bello, el contacto con la naturaleza, una espiritualidad que está allí. Para mí es muy importante la percepción de estos instantes. En cuanto a la luz, creo que ella nos hace universales: nos llega de astros lejanos, nos hace percibir la relación de la tierra con el cosmos. Para mí, la luz es vivificante. Tengo escrita una larga serie de poemas entorno a la luz. El pueblo donde yo crecí, estando muy alto, es un pueblo solar: durante el mediodía, uno percibe el sol muy fuerte, casi se siente el tacto de la luz sobre la piel, hay una luminosidad extraordinaria. Muchos poetas, especialmente los europeos, me han dicho: "Su percepción de la luz es más mediterránea que mexicana". Normalmente los poetas mexicanos, cuando describen estos fenómenos, se fijan más bien en los colores tropicales que en la luz.

T.S.: Mi próxima pregunta está relacionada de alguna manera con la anterior, porque concierne al sentimiento religioso de su poesía. A veces usted menciona en sus poemas a Dios junto con la luz, y esto naturalmente se encuentra en la tradición del misticismo cristiano, donde en el panteísmo se da también la asociación con la naturaleza. ¿Podría quizás decirme si está de acuerdo y si esta observación le parece correcta?

H.A.: Es correcta. Creo que soy casi un poeta religioso sin religión. Yo fui educado como católico cuando era niño, pero en un catolicismo muy liberal. Mi padre había sido un griego ortodoxo, y mi madre católica. Pero la mía no fue una familia religiosa; mi padre iba a la iglesia una sola vez al año. Me veo aún de niño en la vieja iglesia mexicana de mi pueblo, donde mi padre iba sólo en Nochevieja: daba gracias a Dios por haberlo dejado vivir ese año y se iba. Se puede decir que yo crecí con la diosa naturaleza. Desde niño obtuve mi percepción de Dios a través de la naturaleza. De una manera casi pagana, yo veía a Dios en los árboles, en las aves y en el cielo. Los santos de bulto en la iglesia no me decían nada. Para mí, el templo de Dios estaba fuera de la iglesia.

Y ahora pienso cada día más que la tierra es un organismo vivo y que hay una inteligencia en la naturaleza que para mí es la presencia de Dios. Yo no podría jamás definir a Dios, pero lo puedo percibir en cada momento como espíritu. Lo que ha sucedido en los últimos años con los telescopios como el "Hubble", que nos han abierto visiones del universo que no conocíamos, ha sido para mí muy importante: incluso he comprado vídeos con estas nuevas imágenes cósmicas, y en el 1991 estuve en el eclipse solar total que hubo en México, cuando la luna cubrió el sol, dándole la forma de un ojo; algunos dijeron "el ojo de Dios".

Cuando leo mis poemas en las escuelas y en las universidades, los adolescentes y los estudiantes se percatan frecuentemente de esa presencia de Dios, que distingue mi poesía de la de muchos poetas contemporáneos. Yo debo mucho a la poesía visionaria occidental del pasado; mis dos poetas alemanes favoritos, con quienes me identifiqué espiritualmente, han sido desde siempre Novalis y Hölderlin. Este último es un poeta solar...

T.S.: Lo que viene de su relación con los antiguos griegos. 
H.A.: Sí, desde luego, es el poeta alemán más griego. Novalis en cambio me gustó por su percepción de la noche, como poeta romántico. En ambos la luz juega un papel central.

T.S.: Ahora me gustaría hacerle una pregunta referente a la métrica que usted utiliza en sus poemas. Casi no he encontrado versos o estrofas tradicionales en su poesía; tengo la impresión de que usted prefiere los versos libres.

H.A.: Sí, eso es cierto.

T.S.: ¿Podría entonces decirme algo sobre las estructuras formales de su poesía?

H.A.: Yo he leído muchos poemas "tradicionales" y comencé a escribir poesía con verso medido y rima, pero más tarde me di cuenta de que el contenido preconfigura la forma del poema. Poco a poco empecé a confiar en la musicalidad instintiva de mis expresiones. Yo escucho atentamente mis frases, y aunque el verso no sea medido, puede tener ritmo y también cierta musicalidad. Cada poema moldea su propia forma. Desde luego tengo mi estilo personal que sigue una determinada línea de desarrollo, pero lo que cuenta para mí es que haya fluidez en mis versos y que parezcan naturales. Yo soy alguien que corrige mucho sus poemas. Cuando escribo un poema, trato de escribirlo completo; pero a veces puedo escribirlo en diez versiones, hasta que le doy una forma satisfactoria. Luego lo vuelvo a tomar y lo corrijo, y a veces hago cambios aun años después. Yo he escrito muchos poemas después de un sueño, al despertar. Para mí hay momentos de extrema lucidez o inspiración, y uso mucho esos cuadernitos que siempre traigo conmigo, donde apunto mis textos. Cuando viajo en avión, o también cuando estoy en la calle, los escribo; y luego los paso a limpio. Y también en mi cuarto, en el buró, en la mesa de noche, siempre tengo cuadernos. Y a veces después de dormir tomo notas. Muchas veces escribo poemas entre sueños. Betty, mi esposa, me compró una pluma que cuando uno la apoyaba proyectaba una luz, pero yo no la podía usar. Más bien que levantarme en la noche e ir a otro cuarto, prefería escribir a oscuras, porque muchas veces se trataba de una sola frase. El sueño para mí tiene mucha importancia como factor de inspiración poética.

T.S.: Esto hace pensar en lo onírico de los surrealistas; pero, como acaba de decirme, usted corrige sus poemas. Entonces el azar no juega el mismo papel en su poesía que en la poesía de los surrealistas.

H.A.: Para mí, el arte surrealista fue más interesante que la poesía de los surrealistas. Lo que más me interesó del surrealismo fue la percepción de esta suprarrealidad, que viene desde los románticos alemanes, y en general de todo lo extrasensorial.

T.S.: Tengo una pregunta a la cual usted casi ya ha respondido y que se refiere a la cuestión de si usted se siente más como el poeta en su torre de marfil o como poeta comprometido. Como me ha dicho, usted empezó con la contemplación de la naturaleza, para dedicarse después a la salvación de esta misma naturaleza. 
H.A.: Yo soy un poeta que nunca perteneció al partido comunista, nunca seguí causas políticas. Yo tenía una especie de aversión por la poesía política, la poesía didáctica y la poesía que predica. Este tipo de poesía me parecía retórica y mala; por ejemplo, la poesía de propaganda de Neruda en sus años del Canto General. Cuando hablo de la naturaleza en mis poemas, no lo hago con una intención didáctica, sino con el ánimo de escribir un buen poema. Lo que yo quiero es que el concepto de naturaleza esté infuso en el poema, no en la superficie.

T.S.: Quisiera hacerle también algunas preguntas referidas a sus novelas. En muchos de sus textos narrativos se encuentran deidades aztecas y otros personajes de la mitología mexicana, por ejemplo los tzitzimime en La leyenda de los soles. ¿Cómo se situaría usted a sí mismo entre las categorías del realismo mágico y de la literatura fantástica, ambas tan importantes para la América Latina?

H.A.: Yo he sido un gran lector de mitología. Como mi padre era griego, empecé con la mitología griega, donde hay dioses con rostro humano. Cuando era adolescente no entendía los dioses mexicanos, que para mí entonces eran herméticos, eran como de otro planeta. Al principio me chocaban, porque eran dioses del sacrificio humano. Yo había crecido con Apolo, Afrodita y Zeus; todo era tan diferente con los dioses mexicanos que se hacía preciso descifrar. Por ejemplo Tezcatlipoca, que es un dios de la noche con muchos atributos y una cierta vaguedad. Un gran erudito alemán, Eduard Seler, escribió unos comentarios al Códice Borgia. Allí da una explicación de todo el mundo mitológico mexicano, algo que me intrigó mucho. Y luego me gustó también Bernardino de Sahagún con su Historia de las cosas de Nueva España, donde se encuentra la descripción de los ritos y costumbres de los antiguos mexicanos.

Cuando se descubrió el Templo Mayor en la Ciudad de México —en el 1978 - , hallaron por ejemplo el disco de la diosa Coyolxauhqui, que es una obra maestra de la escultura azteca. Allí la imagen de la diosa está desmembrada, parece órganos en rotación. Yo iba mucho a ver esas esculturas y hablaba también con los arqueólogos. México es el sueño de todo arqueólogo: dondequiera que uno mire hay una pirámide, cuevas y muchas otras cosas. Durante las excavaciones del Templo Mayor, pude ver algo tan terrible y fascinante como esas calaveras con cuchillos de obsidiana que pasan de la nuca a la boca. Era el mundo del sacrificio humano, el mundo de la muerte y de la mitología, un mundo muy distinto del mío.

En la conducta de los mexicanos actuales vi la supervivencia de ese mundo mágico, la presencia de los dioses antiguos. Debajo de un aparente occidentalismo están escondidas unas raíces muy profundas. Yo incorporé todo eso a mis poesías y a mis novelas; por ejemplo, La leyenda de los soles es como el retorno de los dioses antiguos de México al mundo actual. Quizás es por mi condición de mestizo que yo percibía este fenómeno. Como mi padre era griego, siempre se le percibió como un extranjero en mi pueblo. Mi padre había vivido en Turquía y en Asia Menor; los habitantes del pueblo a veces lo llamaban turco 
o judío o árabe; y como mi padre también había pasado por Bélgica lo llamaban también belga. Había una confusión en la gente del pueblo sobre la nacionalidad de mi padre. Esta misma condición de extranjero me hacía ver lo mexicano con ojos diferentes: no desde dentro, sino desde fuera.

T.S.: He notado que en muchas de sus novelas hay conflictos entre culturas diferentes: en El Señor de los Últimos Días entre árabes y cristianos en la España del año mil; en 1492, Vida y tiempos de Juan Cabezón de Castilla entre árabes, cristianos y judíos en la época de los Reyes Católicos; en Memorias del Nuevo Mundo entre indígenas y conquistadores sobre la tierra de México. Estos conflictos se resuelven muchas veces con un mestizaje cultural, o - para utilizar un término muy de moda entre los hispanistas alemanes - con una especie de "hibridación". Por ejemplo, en Memorias del Nuevo Mundo destaca la figura del conquistador Gonzalo Dávila, que al final de la novela se convierte en víctima de un ritual azteca. ¿Esto significó para usted la fusión de la cultura española con la cultura mexicana?

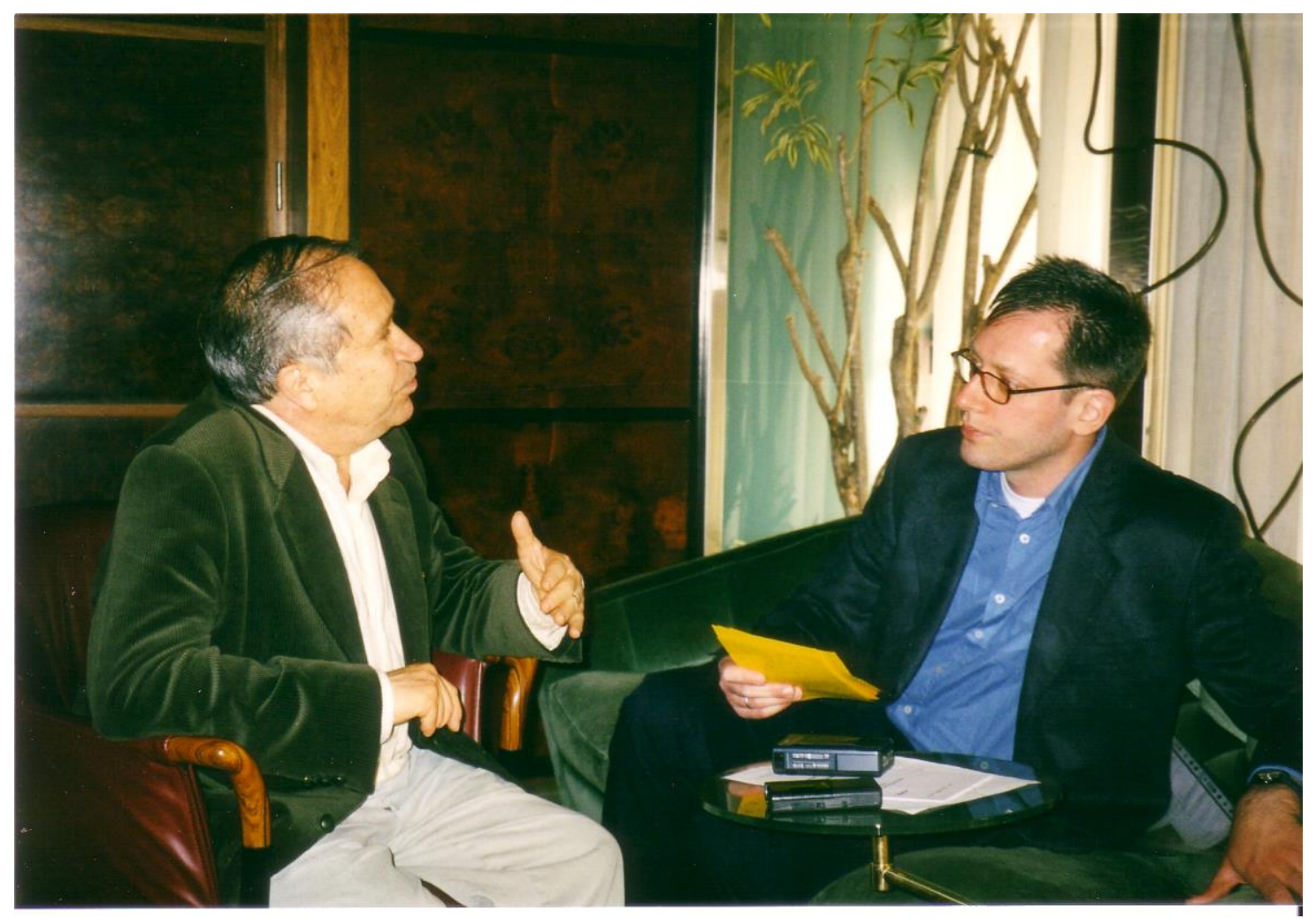

Homero Aridjis y Thomas Stauder durante el coloquio, en Murcia, abril 2003

(foto: Angela Barwig).

H.A.: Es una integración a través de una inmolación. Tengo un poema que se llama "Un conquistador anónimo recuerda su paso por las tierras nuevas", donde el conquistador se convierte en algo así como un dios. Me fascinó el hecho de que los indígenas tomaran la llegada de Cortés por el regreso de un dios, de Quetzalcóatl. Hay también una transformación social de los conquistadores: Cortés era de baja extracción y en México recibió un título 
nobiliario, llegó a llamarse el marqués del Valle. Es un comportamiento que pude observar también en los habitantes de mi pueblo ante mi padre: a veces había una cierta admiración por el extranjero que luego se transformaba en agresión contra ese mismo extranjero. De pequeño me sentía distinto de los otros niños por ser hijo de un griego en un pueblo de campesinos mexicanos. Pero también cuando fui mayor viví tres años en Nueva York; al hablar el inglés con acento, uno se convertía en extranjero, en una categoría social que llamaban "latino" (ahora se dice "hispano"). Quienquiera que hablara español, fuera mexicano, argentino, boliviano, puertorriqueño o cubano, era "latino". Para mí no había designación más absurda; pensaba en la literatura latina, en Virgilio y Horacio. Llamar a un boliviano "latino" me parecía tan absurdo como llamar a un africano de Nigeria "griego". Luego viví también durante algunos años en Holanda. Cuando uno vive fuera de su país, se convierte en una especie de turista de lujo situado en una especie de limbo cultural. Se encuentra en una sociedad, pero no está integrado en ella. Todas las actividades cotidianas, políticas y laborales son como ajenas a uno. Yo no entendía el holandés, no tenía un verdadero contacto con la gente. Entonces me di cuenta de todos esos problemas de conflictos de culturas.

T.S.: Uno de los temas de sus novelas que está de una cierta manera relacionado con los aspectos que hemos tocado hasta ahora es la violencia en México. Cuando se observa la conexión entre sus novelas 1492, Vida y tiempos de Juan Cabezón de Castilla y Memorias del Nuevo Mundo, que tienen en común el mismo protagonista y el fenómeno de la intolerancia ideológica y étnica, uno tiene la impresión de que los conquistadores trajeron la violencia desde España hasta México. Sin embargo, no hay que olvidar que ya los aztecas habían tenido sus ritos sangrientos. ¿Como ve usted el papel y las causas de la violencia en la historia de México?

H.A.: Yo soy de los que piensan que antes de la "Conquista de México" se habían dado ya varias conquistas en México: los aztecas conquistaron a los mayas, a los zapotecas y a otros grupos étnicos. Había mucha violencia en el interior de México. Y luego los aztecas tenían una cultura del sacrificio humano; es algo que me impresionó mucho cuando leí las descripciones de Bernardino de Sahagún. Los españoles llegaron a México durante la época de la Inquisición en Europa, que era también una forma de sacrificio humano. A los españoles no les gusta que uno se lo diga, pero en las plazas de Toledo, Sevilla, Córdoba, Ávila y Zaragoza se procedía a la quema de judíos conversos durante las fiestas de San Pablo y San Pedro.

Además, cuando era niño, podía observar en mi pueblo en México una forma de violencia más personalizada: cuando salía los domingos a las calles del pueblo, veía escenas de violencia familiar, borrachos que tomaban un puñal o una pistola para herir o matar. Eso es diferente de la violencia urbana en las grandes ciudades como Nueva York, donde la gente vive de manera más anónima. En mi pueblo en cambio se trataba de personas que yo conocía y que luego se transformaban en criminales por sus actos violentos. 
Cada país tiene su propia forma de violencia, con características culturales específicas. Los alemanes tendrán una manera de expresar su violencia, los mexicanos tienen la suya. Y a veces hay un azteca que sale de debajo de una máscara de civilización. Esto se podía observar en los policías y militares durante la masacre de los estudiantes en el 1968. En las imágenes que nos quedan de estos acontecimientos, se ve a un soldado disparando contra un estudiante y riendo al mismo tiempo. Yo lo veo como una calavera azteca, feliz matando, que cree que es algo muy divertido. De esta violencia típicamente mexicana he hecho el tema de muchas de mis novelas. Para mí es como la irrupción del mal en la vida cotidiana y apacible; es algo bíblico, como la serpiente en el Paraíso.

T.S.: Mi próxima pregunta está en estrecha relación con el problema de la violencia y concierne la cuestión de la identidad nacional mexicana. Hay un cuento suyo intitulado "Noche de Independencia", publicado en el 1978; el lector de este cuento no recibe la impresión de que los mexicanos de a pie conozcan muy bien la historia de su país. Usted luego ha tratado también el tema de la identidad nacional en muchos de sus poemas, ¿quizás hay en eso un esfuerzo por su parte de mejorar la conciencia histórica de sus compatriotas?

H.A.: Es verdad que los mexicanos muchas veces tienen ideas muy vagas sobre su propia historia; la educación es muy deficiente. A pesar de esta ignorancia, hay mucho patriotismo en México.

T.S.: Me gustaría saber cómo ve usted sus propias novelas sobre el fondo de la "nueva novela histórica" latinoamericana. Tengo la impresión de que en sus novelas hay la misma heterogeneidad de la mirada que en la "nueva novela histórica" de otros autores. Quizás podría decirme algo de su manera particular de analizar y narrar acontecimientos históricos...

H.A.: Muchas veces, cuando uno escribe una novela histórica, se parte de un período o de un personaje específico. Pero luego los temas de la novela se van modificando de acuerdo con la investigación misma. A veces surgen situaciones históricas que uno no ha contemplado al comienzo. Por ejemplo, cuando yo empecé a escribir 1492, Vida y tiempos de Juan Cabezón de Castilla, me centré en Cristóbal Colón, un personaje que me fascinaba cuando era niño y adolescente; sin embargo, me di cuenta que Colón no podía ser el verdadero protagonista de mi novela, porque antes de 1492 su vida es muy oscura, y después de 1492 él mismo escribió todo. Luego comprendí que el tema más interesante para mi novela era la Inquisición española: había personajes como fray Tomás de Torquemada y muchos detalles históricos que nunca habían sido novelados. Tuve esta ocurrencia gracias a los documentos sobre la vida cotidiana que de aquella época fui encontrando.

T.S.: Finalmente querría preguntarle todavía cuál es o ha sido su relación personal con algunos de los grandes escritores mexicanos del siglo XX. He leído un artículo suyo en el que narra su relación con Octavio Paz. Quizás podría decirme también cuál ha sido para usted la importancia de autores como Juan Rulfo o Carlos Fuentes. 
H.A.: Yo conocí desde muy joven a Juan Rulfo. Cuando llegué a la Ciudad de México, entré en el Centro Mexicano de Escritores; allí encontré dos escritores importantes de aquella época, Juan Rulfo y Juan José Arreola. Precisamente con este último yo jugaba entonces mucho al ajedrez. En cuanto a Rulfo, su obra - Pedro Páramo y El llano en llamas - fue conocida en México sólo una vez que fuera traducida al alemán; fue una especie efecto bumerang. El mundo de Rulfo era el mundo rural mexicano, pero su obra trascendía la literatura local y tenía un valor universal. Juan Rulfo, como persona, fue un hombre muy hermético, huraño, difícil, incluso neurótico. Cuando lo conocí tenía un grave problema de alcoholismo. Sus cuentos se fueron valorizando más con el paso de los años; sin embargo, para mí eran muy diferentes de mi obra. En este tiempo yo todavía no escribía novelas, sino sólo poesía.

Respecto a Octavio Paz, cuando yo tenía 21 años, le mandé a París mi primer libro, La tumba de Filidor, y él me mandó una carta muy entusiasta. A partir de entonces tuve con él una relación poética verdaderamente importante. Cuando vino a México después de haber sido designado embajador en la India, lo conocí personalmente y nos hicimos amigos. Casi llegó a considerarse a sí mismo como el descubridor de mi obra poética, mantuvimos mucha correspondencia literaria. Pero cuando hay una diferencia de edad entre dos autores, las relaciones cambian con el tiempo. Tuvimos una gran amistad al comienzo; sin embargo, en los últimos años de la vida de Octavio Paz se produjo un distanciamiento entre nosotros. Se había despertado el sentido de la competencia; yo ya no era un poeta joven, sino un poeta con obra propia. Cuando veo las cartas que Octavio Paz me escribió en los años sesenta y setenta me doy cuenta de que están llenas de afecto; luego, en los años ochenta, bajaron de tono. Con Rulfo la relación fue más lineal: él no competía conmigo como poeta, y yo no competía con él como prosista.

Con Carlos Fuentes mi relación ha sido muy ajena; es un autor con quien casi no tuve relación personal y tampoco literaria. Pero hay otros autores latinoamericanos que fueron importantes para mí: conocí a Borges y a Neruda; a pesar de la diferencia de edad y del hecho que vivían en otros países, nuestros encuentros fueron muy cordiales.

El coloquio tuvo lugar el 2 de abril de 2003 en Murcia. 